\title{
MAKNA ROHANI DALAM EKSEGESIS PRA-MODERN: Sebuah Pengantar Kepada Teologi Eksegesis Henri de Lubac
}

\author{
Edy Jhon Piter Gurning*
}

\begin{abstract}
Abstrak: Dalam 25 tahun terakhir ini, Theological Interpretation of Scripture (TIS) berkembang dan menjadi pokok diskusi para sarjana biblika dan teologi sistematika. Sebagai sebuah cara untuk memahami Alkitab, TIS mengapresiasi metode hermeneutika pramodern. Bertentangan dengan pemahaman modern bahwa hanya ada satu makna dalam teks, para pendukung TIS mempercayai ada banyak level makna dalam teks Alkitab. Penulis akan berargumentasi untuk membuktikan kebenaran argumen akan adanya banyak level makna dalam teks Alkitab dengan menelusuri pemikiran Henri de Lubac.
\end{abstract}

Abstract: In the last 25 years, Theological Interpretation of Scripture (TIS) has developed and become the subject of discussion of scholars of biblical and systematic theology. As a way to understand the Bible, TIS appreciates the pre-modern hermeneutics method. Contrary to the modern understanding that there is only one meaning in the text, TIS supporters believe there are many levels of meaning in the biblical text. The author will argue for the existence of many levels of meaning in the biblical text by tracing Henri de Lubac's thoughts.

Kata-kata kunci: De Lubac, makna literal, makna rohani, level makna, hermeneutika pra-modern, Theological Interpretation of Scripture.

* Penulis adalah alumni STT Amanat Agung pada program Magister Teologi (M.Th.). Penulis dapat dihubungi melalui email: gninrugyde@ yahoo.com. 


\section{Pendahuluan}

Sejak zaman Bapa-Bapa Gereja sampai abad pertengahan, Alkitab telah mulai ditafsirkan dari sudut pandang teologi sistematika, dengan berbagai metode penafsiran yang berlaku saat itu. ${ }^{1}$ Namun pengaruh modernitas yang sangat mengagungkan peran rasio, dan secara khusus sejak pidato pengukuhan J. P. Gabler sebagai guru besar di Universitas Altdorf, Jerman pada tanggal 30 Maret 1787 yang berjudul "An Oration on the Proper Distinction between Biblical and Dogmatic Theology and the Specific Objectives of Each,"2 perlahan-lahan penafsiran teologis yang berlangsung selama 1700 tahun itu meredup. Sebagaimana judul pidatonya, Gabler mengajukan proposal agar setiap sarjana membedakan antara teologi biblika dan teologi sistematika. Sejak itulah teologi biblika dan teologi sistematika seakan-akan mengalami "perceraian." Untuk

1. Karya monumental Henri de Lubac, Medieval Exegesis, yang diterjemahkan ke dalam Bahasa Inggris yang terdiri dari 3 jilid dan diterbitkan oleh Eerdmans, merupakan studi terbaik dan terlengkap yang menjabarkan tentang penafsiran teologis sejak Bapa-bapa Gereja sampai abad pertengahan. Dalam kata pengantarnya terhadap karya Henri de Lubac, Medieval Exegesis: The Four Senses of Scripture, vol. 1, terj. Mark Sebanc (Grand Rapids, Eerdmans, 1998), x, Robert Wilken mengatakan bahwa dalam ke-3 jilid buku Medieval Exegesis ini, de Lubac membuktikan dan menjabarkan dengan jelas bahwa sejak Bapa-bapa Gereja hingga Abad Pertengahan "biblical exegesis was not a specialized discipline carried on independently of theology; it was theology."

2. Untuk refleksi awal atas signifikansi Gabler, lihat Charles H. H. Scobie, The Ways of Our God: An Approach to Biblical Theology (Grand Rapids: Eerdmans, 2003), 5,15-16 dan Craig G. Bartholomew, "Biblical Theology," dalam Dictionary for Theological Interpretation of the Bible (DTIB), ed. Kevin J. Vanhoozer et al. (Grand Rapids: Baker, 2005), 84-90. 
sampai kepada kebenaran yang objektif sebagaimana yang diinginkan Gabler, penafsir haruslah bersikap kritis. Kritis yang dimaksud adalah dengan berfokus pada sejarah, mencari relasi sebab akibat di balik peristiwa dan kejadian. Hal-hal inilah yang membuat para sarjana modern membuang semua unsur supranatural yang dianggap tidak bisa dikritisi secara objektif. Alkitab dipandang hanya sebagai sebuah buku tulisan manusia tanpa adanya inspirasi llahi, dan aktivitas membaca Alkitab disamakan dengan membaca buku lainnya. ${ }^{3}$

Peristiwa kedua yang semakin meredupkan penafsiran teologis terhadap Alkitab terjadi pada tahun 1859, ketika Benjamin Jowett, yang merupakan Profesor Teologi dan Yunani Klasik di Universitas Oxford, menerbitkan esainya yang sangat terkenal yang berjudul "On the Interpretation of Scripture." Jowett berargumen, "Scripture has one meaning - the meaning which it had in the mind of the Prophet or Evangelist who first uttered or wrote, to the hearers or readers who first received it." ${ }^{4}$ Hanya ada makna tunggal, yaitu makna literal yang dimaksudkan oleh penulis Alkitab kepada pembacanya mula-mula yang harus ditafsirkan secara kritis untuk mendapatkan kebenaran yang obyektif. Untuk mendapatkan makna yang objektif, segala

3. Untuk gambaran singkat bagaimana penafsiran teologis atas Kitab Suci meredup akibat kebangkitan analisis sejarah, baca Daniel Treier, Introducing Theological Interpretation of Scripture: Recovering a Christian Practice (Grand Rapids: Baker, 2008), 11-14.

4. David C. Steinmetz, "The Superiority of Pre-Critical Exegesis," dalam The Theological Interpretation of Scripture: Classic and Contemporary Readings, ed. Stephen Fowl (Oxford: Blackwell, 1997), 26. 
unsur yang dianggap subjektif, seperti pandangan teologi si penafsir, harus ditinggalkan. Tidak ada makna bagi pembaca saat ini, karena penulis Alkitab hanya memaksudkannya bagi pembaca dan pendengarnya mula-mula. Satu-satunya metode penafsiran yang sah untuk mendapatkan kebenaran objektif tunggal tersebut adalah metode analisa sejarah (historical criticism).

Kedua peristiwa inilah yang membuat terjadinya skisma antara studi biblika dan studi teologi sistematika yang sudah berlangsung selama dua abad. Namun dalam 25 tahun terakhir ini, berkembang suatu metode penafsiran Alkitab yang dikenal dengan istilah Theological Interpretation of Scripture (TIS) yang mencoba untuk menjembatani kedua disiplin ilmu ini, yang selama ini berjalan sendiri-sendiri dan tidak saling berelasi. ${ }^{5}$

5. Untuk pendahuluan dan evaluasi singkat bagi metode Theological Interpretation of Scripture (TIS), baca artikel Gregg R. Allison, "Theological Interpretation of Scripture: An Introduction and Preliminary Evaluation," Southern Baptist Journal of Theology 14/2 (2010). Kritik terbaik terhadap gerakan ini ditulis dengan sangat seimbang oleh D. A. Carson, "Theological Interpretation of Scripture: Yes, But . ..," dalam Theological Commentary: Evangelical Perspective, ed. Michael Allen (London: T \& T Clark, 2011). Gerakan TIS ini telah menerbitkan beragam literatur diantaranya sebuah jurnal yang bernama Journal of Theological Interpretation (Winona Lake: Eisenbrauns, 2007-); seri tafsiran Alkitab seperti The Ancient Christian Commentary on Scripture (Downers Grove: InterVarsity, 1998); Belief: A Theological Commentary on the Bible (Louisville: Westminster John Knox, 2010-); The Brazos Theological Commentary on the Bible (Grand Rapids: Brazos, 2006-); The Church's Bible (Grand Rapids: Eerdmans, 2003-); The Two Horizons New Testament Commentary (Grand Rapids: Eerdmans, 2005), The Two Horizons Old Testament Commentary (Grand Rapids: Eerdmans, 2008-); dan juga kamus seperti The Dictionary for the Theological Interpretation of the Bible, ed. Kevin J. Vanhoozer, Craig G. Bartholomew, Daniel J. Treier, dan N. T. Wright (Grand Rapids: Baker, 2005) dan The 
TIS tidak mudah untuk didefinisikan. Charles Trimm menawarkan sebuah spektrum terhadap pendekatan eksegesis yang dibangun di atas dua kutub: kutub sejarah di bagian kiri dan kutub teologi di sebelah kanan. ${ }^{6}$ Spektrum pertama menekankan analisis sejarah dan tidak menaruh perhatian pada aspek teologis disebut Trimm sebagai theologically opposed exegesis (seperti John Barton, James Barr, Heikki Raisanen, ICCC, AB, JPS Torah). Spektrum kedua masih menaruh perhatian pada sejarah tetapi terbuka kepada aspek teologis disebut Trimm sebagai theologically open exegesis (seperti Raymond Brown, Joseph Fitzmyer, NICNT \& NICOT, NAC, Interpretation). Spektrum ketiga adalah theologically curious exegesis. Para sarjana di spektrum ketiga ini, menurut Trimm, mempunyai rasa ingin tahu tentang pertanyaan-pertanyaan teologis yang terkait dengan teks, meskipun jawaban atas pertanyaanpertanyaan teologis tersebut tidak ditentukan oleh teologi. Sejarah masih merupakan hal yang penting bagi para sarjana di spektrum ketiga ini, seperti halnya Markus Bockmuehl, Walter Moberly, Daniel Treier, Kevin Vanhoozer, Luke T. Johnson, Karl Barth, Two Horizons Commentary, yang para penafsir seri THC ini umumnya adalah sarjana biblika seperti Stephen Fowl, Joel Green, Ruth Anne Reese, Geoffrey Grogan. Spektrum kedua dan ketiga ini mirip dan terkesan

Dictionary of Major Biblical Interpreters, ed. Donald McKim (Downers Grove: InterVarsity, 2007).

6. Charles Trimm, "Evangelicals, Theology, and Biblical Interpretation: Reflection on the Theological Interpretation of Scripture," Bulletin of Biblical Research 20/3 (2010): 319-27. 
rancu. Namun kedua spektrum tersebut setidaknya menunjukkan pendekatan hermeneutika yang memperhatikan eksegesis sekaligus aspek teologisnya. Kaum Injili umumnya ada pada spektrum kedua dan ketiga. Sedangkan spektrum keempat-yang hanya sedikit tertarik dengan makna asli dan konteks sejarah teks Alkitab tetapi membaca teks Alkitab sepenuhnya secara teologis-disebut Trimm sebagai theologically focused exegesis (seperti Henri de Lubac, Yves Congar, Brazos Theological Commentary on the Bible, di mana umumnya penulis dalam seri BTCB ini merupakan teolog seperti Jaroslav Pelikan, Stanley Hauerwas, Peter Leithart, Matthew Levering). Perbedaan inilah yang membuat pendefinisian TIS sukar dan tidak seragam.

Secara sederhana, TIS merupakan metode hermeneutika yang menggunakan proposisi teologis untuk memahami Alkitab. ${ }^{7}$ Salah satu ciri TIS adalah apresiasi mereka terhadap metode penafsiran pra-modern yang mempercayai bahwa tidak hanya ada satu makna, tetapi ada beberapa level makna dalam teks Alkitab. Para pendukung gerakan TIS ini merumuskannya demikian,

Text of Scripture do not have a single meaning limited to the intent of the original author. In accord with Jewish and Christian traditions, we affirm that Scripture has multiple complex senses given by God, the author of the whole drama. ${ }^{8}$

7. Allison, Theological Interpretation, 29.

8. Treir, Introducing Theological Interpretation of Scripture, 199. 
Konsep tentang banyak level makna dalam Alkitab yang menjadi fokus penulis dalam artikel ini merupakan ciri TIS yang keempat. Ada sembilan ciri TIS yang diajukan oleh sebuah tim yang menamakan diri "Scripture Project" yang terdiri dari para pendukung TIS, yang berkumpul selama empat tahun untuk mendiskusikannya. Para sarjana itu diantaranya Ellen F. Davis, Richard Hays, Robert W. Jenson, Richard Bauckham, David Steinmetz, Brian Daley dan R. W. L. Moberly. Kesembilan ciri TIS ini dijabarkan dengan singkat oleh Treir sebagai berikut:

1. Scripture truthfully tells the story of God's action of creating, judging, and saving the world.

2. Scripture is rightly understood in light of church's Rule of Faith as a coherent dramatic narrative.

3. Faithful interpretation of Scripture requires an engagement with the entire narrative: the New Testament cannot be rightly understood apart from the Old, nor can the Old be rightly understood apart from the New.

4. Text of Scripture do not have a single meaning limited to the intent of the original author. In accord with Jewish and Christian traditions, we affirm that Scripture has multiple complex senses given by God, the author of the whole drama.

5. The four canonical Gospels narrate the truth about Jesus.

6. Faithful interpretation of Scripture invites and presupposes participation in the community brought into being by God's redemptive action-church.

7. The saints of the church provide guidance in how to interpret and perform Scripture.

8. Christians need to read the Bible in dialogue with diverse others outside the church.

9. We live in the tension between the "already" and the "not yet" of kingdom of God; consequently, Scripture calls the church to ongoing discernment, to continually fresh 
rereadings of the text in light of the Holy Spirit's ongoing work in the world. ${ }^{9}$

Meskipun kesembilan ciri ini diterima sebagai ciri umum gerakan TIS, tapi tidak semua pendukung TIS setuju dengannya. Beberapa pendukung TIS, misalnya, menolak ciri keempat bahwa Alkitab memiliki beberapa level makna. Beberapa tokoh tersebut adalah Kevin Vanhoozer dari kalangan Injili, David Tracy dari kelompok Revisionist, dan Hans Frei dari kelompok Post Liberal. ${ }^{10}$

\section{Ketidakbercukupan Makna Tunggal}

Sebelum menjabarkan argumentasi bahwa ada level makna dalam Alkitab, terlebih dahulu penulis akan membuktikan bahwa makna tunggal objektif, yang menjadi ciri khas hermeneutika modern, tidak memadai. David C. Steinmetz membuat sebuah argumen yang menjadi populer tentang hal ini:

How was a French parish priest in 1150 to understand Psalm 137, which bemoans captivity in Babylon, makes rude remarks about Edomites, expresses an ineradicable longing for a glimpse of Jerusalem, and pronounces a blessing on anyone who avenges the destruction of the Temple by dashing Babylonian children against a rock? The priest lives in Concale,

9. Treir, Introducing Theological Interpretation of Scripture, 199202.

10. Untuk kritik terhadap pandangan ketiga tokoh ini dan mengapa makna spiritual itu adalah sesuatu hal yang pasti, baca artikel Kevin Storer, "Theological Interpretation and the Spiritual Sense of Scripture: Henri de Lubac's Retrieval of a Christological Hermeneutic of Presence," Journal of Theological Interpretation 7/1 (2013): 79-96. 
not Babylon, has no personal quarrel with Edomites, cherishes no ambitions to visit Jerusalem (though he might fancy a holiday in Paris), and is expressly forbidden by Jesus to avenge himself on his enemies. Unless Psalm 137 has more than one possible meaning, it cannot be used as a prayer by the Church and must be rejected as a lament belonging exclusively to the piety of ancient Israel. ${ }^{11}$

Banyak teks dalam Perjanjian Lama, yang jika ditafsirkan secara literal dengan memakai metode analisa sejarah, menjadi teks-teks yang sulit untuk dipahami dan menjadi "hukum tertulis yang mematikan." Namun, teks-teks sulit itu tidak terbatas hanya dalam Perjanjian Lama, tetapi juga terdapat dalam Perjanjian Baru. Origenes, seorang Bapa Gereja yang juga merupakan seorang penafsir Alkitab, menunjukkan hal tersebut saat menafsirkan teks 2 Korintus 3:6 demikian:

For even in the Gospels, it is "the letter" that "kills." Not only in the Old Testament is "the letter that kills" found; there is also in the New Testament "the letter that kills" - that one who does not spiritually perceive what is said. For, if you follow according to the letter which is said, "Unless you eat my flesh and drink my blood," this "letter kills." Do you want me to bring out of the gospel for you another "letter" that "kills?" He says, "Let the one who does not have a sword sell his tunic and buy a sword." Behold, this is the letter of the gospel, but "it kills." But, if you take it spiritually, it does not kill, but there is in it "a spirit that gives life." For this reason, receive spiritually what is said

11. Steinmetz, The Superiority of Pre-Critical Exegesis, 28. 
either in the law or in the Gospels because "the spiritual one judges all things but one is not judged by anyone. ${ }^{12}$

Semua tulisan yang diilhamkan Roh Kudus adalah firman Allah yang berguna bagi pembaca saat ini, termasuk teks-teks sulit dalam Alkitab, seperti contohnya Mazmur kutukan. Namun jika teks-teks ini hanya dimaknai sesuai eksegesis modern, Bapa-bapa Gereja menyebutkannya sebagai "hukum tertulis yang mematikan." Saat diperhadapkan kepada teks-teks sulit dalam Alkitab, Origenes berkata, "Scripture possesses a deeper meaning that opens itself to those filled with the Spirit."13 Hukum yang tertulis itu bersifat mematikan karena memang ada makna lain di dalam Alkitab selain makna literal obyektif, yaitu makna spiritual. Tokoh yang paling menonjol dalam membangkitkan kembali kesadaran akan pentingnya metode eksegesis pra-modern yang memercayai adanya dua level makna dalam Kitab Suci adalah Henri de Lubac.

\section{Sejarah Singkat Henri de Lubac}

Henri de Lubac lahir di Cambrai, Perancis, 20 Februari 1896. la merupakan imam dari ordo Yesuit dan dianggap sebagai salah satu teolog Katolik yang berpengaruh di abad ke-20. Beberapa karyanya yang sangat terkenal di antaranya Catholicism (1938), yang

12. Dikutip dalam Gerald Bray, ed., "1-2 Corinthians," Ancient Christian Commentary on Scripture NT 7 (Illinois: InterVarsity, 1999), 216.

13. Christopher Hall, Reading Scripture with the Church Father (Downers Grove: InterVarsity, 1998), 151. 
menekankan solidaritas umat manusia; Surnaturel (1946) yang menantang pemahaman Thomas Aquinas tentang peran natur; dan Corpus Mysticum (1949) yang bermaksud memulihkan teologi eukaristi berdasarkan eksegesis Bapa-bapa Gereja; dan Histoire et Esprit (1950) sebuah studi tentang hermeneutika Origenes.

Meskipun sempat hidup terasing selama 10 tahun dan bukubukunya serta pemikirannya dianggap berbahaya, nama baiknya kembali dipulihkan dan Paus Yohanes XXIII bahkan menjadikannya penasihat teologi bagi Konsili Vatikan Kedua pada tahun 1960. De Lubac dianggap aktor utama di balik beberapa dokumen penting gereja Katolik seperti Dei Verbum (dogma tentang pewahyuan ilahi), Lumen Gentium (dogma tentang Gereja), dan Gaudium et Spes (konstitusi tentang peran gereja di dunia modern). Karya monumentalnya, Exegese Medievale (1959-1965), yang terdiri dari 4 jilid, membangkitkan kembali minat kepada prinsip-prinsip eksegesis Alkitab pra-modern.

Seluruh pemikiran de Lubac bertujuan untuk memulihkan kembali kekristenan dan peran gereja di zaman modern dengan kembali kepada akar sejarahnya (ressourcement), yaitu Bapa-bapa Gereja dan para teolog abad pertengahan. Gerakan ini-yang dikerjakan de Lubac bersama dengan beberapa sarjana teologi Perancis lainnya diantaranya Jean Danielou, Henri Bouillard, Pierre 
Teilhard de Chardin, Hans Urs von Balthasar-dikenal dengan istilah The New Theology. ${ }^{14}$

\section{Pemikiran Henri de Lubac tentang Dua Makna dalam Alkitab}

Setelah mempelajari tulisan Bapa-bapa Gereja sampai tulisan para sarjana Alkitab abad pertengahan, de Lubac mengatakan, "The Christian tradition understands that Scripture has two meanings." ${ }^{15}$ Sejak diperkenalkan oleh John Cassian (c. 360-435 AD), secara tradisional diterima akan adanya empat level makna dalam pembacaan Alkitab, yaitu makna literal, makna alegoris, makna tropologis atau moral, dan makna anagogi atau eskatologis. Henri de Lubac menegaskan bahwa sesungguhnya hanya ada dua level makna dalam Alkitab, yaitu makna literal (atau historis) dan makna rohani (spiritual).

Makna rohani itu sendiri dapat bersifat alegoris, tropologis dan anagogis. Ketiganya merupakan tiga aspek dari satu Misteri: alegori adalah Misteri Kristus yang diteruskan kepada gereja untuk dipercayai, tropologi merupakan aplikasi moral yang memberitahukan apa yang harus kita lakukan sebagai seorang Kristen dalam menghidupi misteri ini, dan anagogi menunjuk kepada

14. Untuk pengantar singkat kehidupan dan peran Henri de Lubac, baca Susan K. Wood, Spiritual Exegesis and the Church in the Theology of Henri de Lubac (Grand Rapids: Eerdmans, 1998), bab 1. Untuk pengantar kepada teologi Lubac, baca Hans Urs von Balthasar, The Theology of Henri de Lubac, terj. J. Fessio, S.J. (San Francisco: Ignatius, 1991).

15. Henri de Lubac, Medieval Exegesis: The Four Senses of Scripture, vol. 1, terj. Mark Sebanc (Grand Rapids: Eerdmans, 1998), 225. 
pengharapan eskatologis. Jika dihubungkan dengan ketiga kebajikan Kristen, maka alegori memberitahukan apa yang perlu kita imani, tropologi memberitahukan apa yang perlu kita lakukan sebagai ungkapan kasih kita, sedangkan anagogi memberitahukan apa yang menjadi pengharapan kita. ${ }^{16}$

Oleh sebab itu, De Lubac menyimpulkan bahwa Alkitab tidak hanya memiliki satu makna saja yaitu makna literal (historis), tetapi dua makna, yaitu makna literal dan makna rohani (spiritual). Beberapa dasar argumen dari pemikiran Lubac antara lain adalah:

\section{Antitesis Paulus}

De Lubac menemukan bahwa teks Paulus dalam 2 Korintus 3:6 menjadi teks kunci bagi Bapa-bapa Gereja akan adanya dua makna dalam Alkitab. Paulus membedakan antara "hukum yang tertulis" dan "roh". "Hukum yang tertulis" inilah yang merupakan makna literal, dan "roh" merujuk kepada makna spiritual. ${ }^{17}$

\section{Kisah Transfigurasi Yesus}

Dengan mengikuti tafsiran Origenes terhadap Matius 17:1-13, de Lubac menguraikan kisah Transfigurasi Yesus ini dengan menyebutkan tiga keunikan. Pertama, dia membedakan adanya dua

16. Untuk pemahaman lebih dalam akan ke-4 level makna dan relasi di antara keempatnya Lih. Wood, Spiritual Exegesis, bab 2.

17. Henri de Lubac, "Spiritual Understanding," dalam The Theological Interpretation of Scripture: Classic and Contemporary Readings, ed. Stephen Fowl (Oxford: Blackwell, 1997), 17. 
kelompok murid: kelompok pertama terdiri dari orang-orang yang dipisahkan Yesus untuk ada bersama-sama dengan-Nya, yaitu Petrus, Yakobus, dan Yohanes; sedangkan kelompok kedua adalah sisa kesembilan murid lainnya. Kedua, adanya dua kelompok murid yang berada di dua lokasi yang berbeda. Yesus memimpin kelompok pertama naik ke atas gunung, sedangkan kelompok lainnya ada di kaki gunung. Ketiga, adanya dua model penampakan yang berbeda kepada dua kelompok ini. Yesus menampakkan kemuliaan keilahianNya kepada ketiga murid yang ada di atas gunung. Sedangkan bagi kelompok yang ada di bawah hanya melihat sisi kemanusiaan Yesus saja.

Demikian juga saat Yesus mengalami transfigurasi, "pakaianNya" sebagaimana "wajah-Nya" juga mengalami transfigurasi. De Lubac mengikuti Origenes yang menafsirkan perubahan wajah dan pakaian Yesus sebagai bentuk penyingkapan identitas Ilahi-Nya, yaitu penyingkapan sesuatu yang rohani.

Pada saat transfigurasi, Musa dan Elia sedang berbicara dengan Yesus yang dimuliakan. Hal ini juga menunjukkan, menurut Origenes, bahwa ketika seseorang membaca Alkitab dalam terang kebenaran Kristus, maka hukum yang diwakili Musa dan kitab nabinabi yang diwakili Elia "will simultaneously appear illuminated and in relation to Christ's glory, i.e., the spiritual sense is revealed."18

18. Dikutip oleh William M. Wright, "The Literal Sense of Scripture According to Henri de Lubac: Insights from Patristic Exegesis of the Transfiguration," Modern Theology 28/2 (April 2012): 256. 
Tafsiran Origenes atas kisah Transfigurasi ini dipakai de Lubac sebagai dasar teologi eksegesis akan adanya dua makna dalam teks Kitab Suci.

Kehadiran Kristus

Kehadiran Kristus dalam Kitab Suci menjadi argumen terpenting bagi de Lubac untuk membuktikan bahwa Alkitab bukan hanya mengandung satu makna, tetapi dua makna, karena kehadiran Kristus membuktikan keharusan adanya makna rohani dalam Kitab Suci. Kevin Strorer menyimpulkan bahwa bagi de Lubac, "the articulation of a spiritual sense is necessary because Christ is present in Scripture to encounter readers." ${ }^{19}$ De Lubac sendiri mengatakan, "The whole body of Divine Scripture, both the Old and the New Testaments, contain the Son of God."20

Karena itulah Kitab Suci akan memimpin kita kepada Kristus. Kristus menjadi satu-satunya Objek dari pembacaan Kitab Suci. Bahkan saat Yesus masih tinggal di bumi, Dia pernah berkata kepada orang-orang Yahudi, "Kamu menyelidiki Kitab Suci . . Kitab Suci itu memberi kesaksian tentang Aku" (Yoh. 5:39). Karena kehadiran Kristus dalam teks Kitab Suci, maka Kristus bukan hanya "the exegesis of Scripture" tetapi la juga "the exegete." ${ }^{21}$ Kristus bukan hanya Objek tetapi juga Subjek dari Kitab Suci. Sebagaimana kisah saat Kristus

19. Kevin Storer, "Theological Interpretation", 91.

20. De Lubac, Medieval Exegesis, vol. 1, 237.

21. De Lubac, Medieval Exegesis, vol. 1, 237-38. 
Yesus berjumpa dengan dua orang dari murid-Nya yang hendak pergi ke sebuah kampung bernama Emmaus, saat mereka tidak memahami segala sesuatu yang dikatakan para nabi tentang Dia.

Lalu Yesus "menjelaskan kepada mereka apa yang tertulis tentang Dia dalam seluruh Kitab Suci, mulai dari kitab-kitab Musa dan segala kitab nabi-nabi" (Luk. 24:27). Setelah Yesus menerangkan Kitab Suci kepada mereka, Lukas kemudian mencatat "Ketika itu terbukalah mata mereka dan mereka pun mengenal Dia" (Luk. 24:31). Momen terbukanya mata kedua murid itu menjadi bukti akan adanya makna lain selain makna literal yang kedua murid itu sudah pahami. Makna lain itu adalah makna rohani, yaitu makna yang didapatkan saat Kristus itu sendiri mengkomunikasikan Diri-Nya melalui teks Kitab Suci. Hal ini hanya mungkin terjadi karena Roh Kudus menginspirasikan baik teks maupun pembaca. ${ }^{22}$ Bagi de Lubac, sebagaimana dipahami oleh Strorer, saat pembaca bergerak dari makna literal kepada makna spiritual, itulah momen ketika Kristus menjumpai pembaca. ${ }^{23}$ Strorer menyimpulkan pemikiran de Lubac dengan mengatakan, "it is Christ who establishes the unique and

22. Storer, "Theological Interpretation", 92. Bagi de Lubac, inspirasi Roh Kudus terjadi bukan hanya saat penulis Alkitab menuliskan Alkitab, tetapi saat pembaca mencoba untuk mencari makna yang dimaksud penulis Alkitab. Ini berbeda dengan Protestan yang membedakan antara inspirasi dan iluminasi Alkitab, di mana inspirasi Roh Kudus terjadi kepada penulis Alkitab sedangkan iluminasi Roh Kudus terjadi kepada pembaca saat ini yang mencoba memahami makna teks Alkitab.

23. Lih. Storer, "Theological Interpretation", 92. 
indispensable spiritual sense of Scripture by his present communicative action." 24

Pentingnya Makna Rohani dalam Pemikiran de Lubac

Bagi de Lubac, makna literal adalah sesuatu yang sangat penting dan tidak boleh dianggap remeh. Tentang makna literal, de Lubac mengatakan, "It cannot be doubted that the literal meaning also comes from the Holy Spirit." ${ }^{25}$ Bukan hanya karena Alkitab diinspirasikan oleh Roh Kudus, sehingga makna literal merupakan sesuatu yang sangat penting, tetapi juga karena "the literal sense of Scripture encompasses the concrete, historical realities of salvation history, which contain, veil, and disclose the divine mystery of the Logos." 26 Meskipun menyadari bahwa Roh Kudus jugalah yang memberi pengertian akan makna literal, tetapi makna rohani bagi de Lubac "bears a special relationship to the Spirit." ${ }^{27}$ Relasi khusus ini dijelaskan de Lubac demikian, "Since the spiritual meaning, . . is not bestowed upon them by the human author of a book, it stems totally from the Spirit. ... There is no resource of human mind, no method, no scientific procedure will ever be enough to make us hear 'the music written on the silent pages of the Holy Book'."28 Makna rohani ini

24. Storer, "Theological Interpretation", 96. Dengan perkataannya ini, sepertinya Strorer memahami bahwa kehadiran Kristus yang dimaksud de Lubac adalah kehadiran yang bersifat ontologis.

25. De Lubac, Spiritual Understanding, 12.

26. Wright, The Literal Sense of Scripture, 253.

27. De Lubac, Spiritual Understanding, 12.

28. De Lubac, Spiritual Understanding, 12. 
tersembunyi dalam makna literal Kitab Suci dan hanya dianugerahkan kepada pembacanya oleh Roh Kudus. Dengan tanpa melupakan peran makna literal sebagai akar dari makna rohani, bagi de Lubac, sumber makna rohani semata-mata berasal dari Roh Kudus.

Hal kedua yang menjadikan makna rohani memiliki relasi yang khusus dengan Roh Kudus adalah karena makna rohani "related to Christ, to the Lord." ${ }^{29}$ De Lubac mengatakan, "Christ cannot be recognized except through the Spirit." $30 \mathrm{~J}$. I. Packer menggemakan pernyataan de Lubac saat ia mencoba menjabarkan relasi antara Roh Kudus, Kitab Suci dan Kristus dengan menyimpulkan bahwa Roh Kudus, yang adalah Roh dari Kitab Suci, selalu menunjuk kepada Kristus. $^{31}$

Relasi khusus dengan Roh Kudus inilah yang menurut de Lubac menunjukkan keunggulan makna rohani dibandingkan makna literal. Dengan mengutip Origenes, Jerome, Ambrosius, de Lubac mengungkapkan keunggulan makna rohani ini dengan mengatakan, "A higher or deeper degree of understanding, more absolute than a

29. De Lubac, Spiritual Understanding, 12.

30. De Lubac, Medieval Exegesis, vol. I, 261.

31. Untuk relasi tak terpisahkan antara Alkitab, Roh Kudus dan Kristus, J.I. Packer mengilustrasikan peran Roh Kudus dalam Kitab Suci seperti sebuah lampu sorot yang menyoroti Yesus. Packer mengatakan, "The Spirit's message to us never, Look at me; listen to me; come tome; get to know me, but always, Look at him, and see his glory; listen to him, and hear his word; go to him, and have life; get to know him, and taste his gift of joy and peace." Baca J. I. Packer, Keep in Step with the Spirit: Finding Fullness in Our Walk with God (Grand Rapids: InterVarsity, 2005), 57. 
literal understanding. From it there follows a more noble, a more august meaning. It is a more sacred kind of understanding, which one receives in order to become perfect." ${ }^{\prime 32}$

\section{Bagaimana Makna Rohani Diperoleh?}

Dengan mengutip seorang tokoh bernama Pseudo-Remigius (437-533 AD), de Lubac mengatakan,"the spiritual understanding is not given to just anyone who happens to be doing research." ${ }^{33}$ Terbukti di zaman modern ini, bagaimana ilmu tafsir begitu berkembang dan muncul sarjana-sarjana yang sangat terpelajar, tetapi justru ada banyak ketidakpuasan terhadap hasil penafsiran Kitab Suci yang dirasakan kering, terlalu ilmiah dan kurang bisa menumbuhkan iman, kasih, dan pengharapan kepada Kristus. Karena itu, untuk mendapatkan makna rohani Kitab Suci dibutuhkan lebih dari sekedar penelitian. Tidak heran de Lubac meneruskan mengutip Pseudo-Remigius dengan berkata, "I welcomed the Holy Spirit and he gave me understanding." ${ }^{34}$ Roh Kudus adalah unsur terpenting dalam penafsiran Kitab Suci. Tidak berhenti di situ, setiap penafsir pun harus mempersiapkan jiwanya untuk menerima makna rohani dari Roh Kudus. Namun bagaimana cara mempersiapkan jiwa? De Lubac memberikan beberapa pedoman.

32. De Lubac, Medieval Exegesis, vol. 1, 226.

33. De Lubac, Medieval Exegesis, vol. 1, 454.

34. De Lubac, Medieval Exegesis, vol. I, 454. 
Semua teks Kitab Suci hanya dapat dipahami secara rohani saat pembaca datang kepada Kristus. De Lubac mengatakan, "Come to him, and you will be enlightened. ... When a man turns to the Lord, the veil is removed." 35 Proses datang kepada Kristus ini mengharuskan adanya pertobatan, karena makna rohani akan tetap tersembunyi bagi orang yang tidak mau datang kepada Kristus, meski ia mempunyai inteligensia dan ilmu tafsir yang hebat. Yang menyingkapkan makna rohani adalah Roh Kudus yang adalah Roh Kristus yang tinggal dalam setiap teks Kitab Suci. Pertobatan yang dimaksud de Lubac bukan hanya saat menerima Kristus sebagai Tuhan, tetapi pertobatan yang terus menerus dari dosa dan keduniawian. Roh Kudus memberitahukan makna Kitab Suci dengan sepenuhnya hanya kepada mereka yang jiwanya terus terbuka kepada Kristus, kepada gereja-Nya, dan kepada orang-orang yang terus berjuang hidup dalam kebenaran dan kesucian. ${ }^{36}$

Dengan mempelajari beberapa Bapa-bapa gereja dan sarjana Alkitab abad pertengahan, de Lubac memberikan syarat rohani lainnya untuk memahami dan menerima makna rohani, yaitu

35. De Lubac, Medieval Exegesis, vol. I, 260.

36. Untuk memahami lebih lanjut relasi jiwa dan teologi eksegesis Henri de Lubac, baca Lewis Ayres, "The Soul and the Reading of Scripture: a Note on Henri de Lubac," Scottish Journal of Theology 61/2 (Mei 2008): 173190. 
kerendahan hati, $^{37}$ kesucian hati, $^{38}$ dan kesempurnaan hidup. ${ }^{39}$ Makna rohani bukanlah hasil dari pencarian intelektual atau teknis tafsir termutakhir, namun menurut de Lubac, "the spiritual understanding is a gift of [the Holy] Spirit," ${ }^{40}$ yang diberikan bukan kepada setiap orang, tetapi hanya kepada orang yang dalam iman datang kepada Yesus sambil hidup dalam kerendahan hati, menjaga kekudusan hatinya sambil terus menjalani kehidupan yang sempurna. De Lubac menyimpulkan, "Only those who transcend earthly desires with their understanding perceive the majesty of Holy Scripture." 41 Kitab Suci-yang berbicara tentang misteri Kristus kepada orang-orang rohani-merupakan sebuah perumpamaan yang tidak terpahami bagi orang-orang dunia. Kitab Suci bukan seperti buku biasa karena Roh Kudus sendiri yang menyingkapkan maknanya

37. De Lubac, Medieval Exegesis, 455n24. De Lubac mengutip Peter Comestor, teolog Perancis abad ke-12,"For unless your humility is greater than the humility of the philosophers, ... you will not touch on the hidden mystery of Sacred Scripture."

38. De Lubac, Medieval Exegesis, 455n25. De Lubac mengutip dari Doctrine Spirituelle, sebuah kumpulan nasihat dan pengajaran seorang Yesuit Perancis yang hidup pada abad ke-16 yang bernama Louis Lallemant, "Holy Scripture is difficult to understand, because in it God speaks according to his perceptions, which are infinitely far removed from ours. But he tempers them in such a way that we can understand them by our purity of heart." De Lubac juga mengutip John Cassian (c.360 - 435 AD), " . . there is no way which human doctrine or worldly learning will ever attain this. Only a mind that is pure will attain it through the illumination of the Holy Spirit" (kutipan di halaman 456n25).

39. De Lubac, Medieval Exegesis, 456 n26. De Lubac mengutip Jerome (c. $347-420$ AD), "You who are complete and perfect, and have the light of a knowledge of the Scriptures within you."

40. De Lubac, Medieval Exegesis, vol. I, 264.

41. De Lubac, Medieval Exegesis, vol. I, 264. 
yang penuh kepada pembacanya yang hidup dalam kekudusan dan kesatuan dengan Allah.

Bagi de Lubac, "Spiritual meaning ... can only be the fruit of a spiritual life." 42 Namun, bukan berarti hermeneutika sebagai sebuah ilmu ditolak dan kecerdasan intelektual dinafikan. Justru, menurut de Lubac, "We need both the learned, in order to help us read Scripture historically, and the spiritual men (who ought to be 'men of the Church') in order to help us arrive at a deeper spiritual understanding of it." ${ }^{43}$ Jika yang pertama membebaskan kita dari ketidaktahuan, yang terakhir memberikan pengertian yang menjauhkan kita dari penafsiran yang kering dan yang membahayakan kehidupan iman. Gereja pra-modern sudah melakukannya sejak dahulu, sebagaimana yang ditegaskan oleh de Lubac dengan mengatakan, "It is part of the Christian patrimony." 44

\section{Batasan bagi Makna Rohani}

Para pakar eksegesis modern tidak sepaham dengan pandangan di atas. Kritik yang sering ditujukan terhadap eksegesis pra-modern ini adalah bahwa penafsiran menjadi sembarangan dan sesuka hati penafsir. ${ }^{45}$ Kritik ini bisa dipahami meski tidak sepenuhnya benar, karena makna rohani itu sendiri terkandung di dalam makna literal. Makna literal itu menjadi semacam pagar yang

42. De Lubac, Spiritual Understanding, 13.

43. De Lubac, Medieval Exegesis, vol. I, 267.

44. De Lubac, Medieval Exegesis, vol. I, 267.

45. Scobie, The Ways of Our God, 89. 
menjaga supaya penafsiran rohani tidak dilakukan sembarangan. De Lubac mengatakan, "We must never seek the spiritual meaning behind the letter, but always within it, just as we do not find the Father behind the Son but in him and through him.." ${ }^{46}$ Tiap makna rohani berakar dalam arti literal Kitab Suci. Karena itulah makna rohani tidak bisa berdiri sendiri terpisah dari makna literal, sebagaimana Perjanjian Lama tidak terpisah dari Perjanjian Baru. Makna rohani terkandung dan tersembunyi dalam makna literal. Dalam bagian bukunya yang lain de Lubac mengatakan demikian:

For the Christian there exist two successive 'Testaments.' The goal of the one that is prior in time is to prepare the way for the second. . . The second arises from the first and does not repudiate it. The second does not destroy the first. In fulfilling it, it gives new life and renews it. It transfigures it. It subsumes it into itself. In a word, it changes its letter into spirit. ${ }^{47}$

Makna literal inilah yang menjadi batasan untuk tidak membuat penafsiran rohani menjadi melenceng. Lebih lagi, sebagaimana yang dikatakan de Lubac, "Even patristic writers who seem most strongly allegorical, such as Origen, seek to ground their allegory in the historical sense." ${ }^{48}$

46. De Lubac, Spiritual Understanding, 10.

47. De Lubac, Medieval Exegesis, vol. 1, 227-228.

48. De Lubac, dikutip dari J. Todd Billings, The Word of God for the People of God: An Entryway to the Theological Interpretation of Scripture (Grand Rapids: Eerdmans, 2010), 178. 
Selain makna literal, batasan kedua yang menjaga Alkitab tidak ditafsirkan secara sembarangan adalah gereja. Di sepanjang Medieval Exegesis, de Lubac berargumen bahwa gerejalah sebagai locus of reading dan sumber ajaran yang menuntun pembaca individu dalam memahami makna rohani Alkitab. De Lubac mengatakan, "Scripture is read by the Church and by the individual only within the Church." ${ }^{49}$ Kita bukanlah yang pertama bergumul dengan teks Alkitab. Roh Kudus telah menyingkapkan makna rohani selama berabad-abad kepada gereja-Nya melalui catatan para penafsir Alkitab untuk menjadi pagar bagi pembaca Kitab Suci sesudahnya. Kita membaca Alkitab tidak sendirian, tetapi kita membaca Alkitab bersama gereja, bersama orang-orang kudus, yang kepada mereka Roh Kudus telah terlebih dahulu memperkenalkan Kristus melalui teks Kitab Suci. ${ }^{50}$ Bagi de Lubac, "There is nothing in sacred Scripture which does not pertain to the Church." ${ }^{51}$

\section{Penafsiran Mazmur 137 Berdasarkan Prinsip Hermeneutika Pra- Modern}

Setelah menyajikan konsep teologi eksegesis Henri de Lubac yang sangat mengapresiasi model hermeneutika pra-modern, ada baiknya juga disertakan salah satu contoh hasil penafsiran Mazmur

49. Hans Urs von Balthasar, The Theology of Henri de Lubac (San Francisco: Ignatius, 1991), 76.

50. Untuk memahami lebih dalam relasi antara gereja dan penafsiran rohani Kitab Suci, baca Wood, Spiritual Exegesis, khususnya bab 3.

51. Wood, Spiritual Exegesis, 38. 
137 berdasarkan metode eksegesis pra-modern. Meskipun de Lubac sendiri tidak ada menuliskan buku tafsiran Alkitab, tetapi teologi eksegesis pra-modern yang tersebar di berbagai karyanya telah memengaruhi banyak teolog dan sarjana biblika sesudahnya, yang kemudian menyediakan kepada kita prinsip hermeneutika teologis untuk mendapatkan makna Mazmur 137 secara penuh, yang dimulai dengan melihat makna literal dan spiritual kata "Yerusalem."

Secara literal Yerusalem adalah kota yang terdapat di Timur Tengah, yang menjadi ibu kota Israel dan pusat ibadah Israel kuno, yang tidak ada relevansinya dengan kita sekarang. Namun Roh Kudus memberikan makna rohani yaitu makna yang lebih penuh. Berdasarkan arti alegoris, Yerusalem merujuk kepada gereja. Sedangkan arti tropologisnya merujuk kepada jiwa individu Kristen (yang dalam konteks ini meratapi gereja Tuhan yang dianiaya), dan arti anagogisnya merujuk kepada pengharapan akan Yerusalem yang baru. Mazmur 137 ini pun menjadi relevan karena menjadi mazmur ratapan bagi tiap jiwa yang sedih melihat gereja Tuhan mengalami aniaya. Namun ia tidak putus asa, karena meski saat ini gereja terjebak dalam dunia yang penuh kebencian akan Kristus dan gerejaNya, setiap orang percaya bisa bersuka cita karena dunia yang penuh kekerasan ini bukanlah dunia mereka. Mereka menantikan dunia lain, yaitu Yerusalem baru. Kutukan terhadap orang Edom (ay. 7) dan Babel (ay. 8-9) ditransfigurasikan menjadi penghukuman atas dunia, daging, dan setan, yang adalah musuh orang percaya sesungguhnya yang bisa merusak iman, kasih, dan pengharapan kita kepada Kristus 
dan firman-Nya. Makna rohani inilah yang membuat kita - saat kita membaca Mazmur 137 ini - bisa bersukacita seperti pemazmur bersukacita. Makna rohani inilah yang bisa mengobarkan dan menumbuhkan kasih kita kepada Allah dan sesama pada saat membaca dan mendoakan Mazmur $137 .{ }^{52}$

\section{Penutup}

Pendekatan-pendekatan hermeneutika terbaru terus berkembang, terutama analisis sejarah yang begitu dominan selama beberapa abad ini. Namun, yang lebih baru tidak selalu berarti lebih baik. ${ }^{53}$ Penafsiran-penafsiran terbaru yang berkembang saat ini kebanyakan dipengaruhi oleh postmodernisme. Baik postmodernisme maupun pramodernisme mempercayai adanya banyak makna dalam sebuah teks. Namun, dalam pemikiran postmodernisme, sebuah teks mempunyai banyak makna karena teks itu sendiri dapat diartikan apa saja sesuai pemahaman pembacanya; sedangkan dalam pemikiran pra-modern, teks Alkitab

52. Steinmetz, The Superiority of Pre-Critical Exegesis, 29-30. Billing dalam The Word of God, 188-93 juga menyajikan penafsiran atas Mazmur 137 berdasarkan metode hermeneutika pra-modern. Untuk contoh penafsiran atas teks lain dengan metode hermeneutika pra-modern, baca Stephen Fowl ed., The Theological Interpretation of Scripture, bab 7-26. Fowl menyertakan dua puluh contoh penafsiran teks Kitab Suci Perjanjian Lama dan Perjanjian Baru, yang bisa memperkaya dan membuat kita lebih memahami bagaimana metode hermeneutika pra-modern ini diterapkan dewasa ini.

53. Bruce Holsinger, The Premodern Condition: Medievalism and the Making of Theory (Chicago: University of Chicago Press, 2005). 
mempunyai level makna karena Roh Kudus-penulis seluruh dramayang menyingkapkannya kepada pembaca. Pemikiran Holsinger sangat menarik, karena salah satu dari kesimpulan Holsinger adalah adalah bahwa dalam memahami makna sebuah teks, para filsuf postmodernisme Perancis dipengaruhi oleh eksegesis pra-modern. Dalam bukunya, Holsinger membahas tokoh-tokoh postmodernisme Perancis seperti Blanchot, Derrida, Lacan, Bourdieu dan Barthes. Barthes sendiri-filsuf postmodernisme yang dibesarkan dalam tradisi Protestan-sangat dipengaruhi oleh pemikiran de Lubac dan ia membaca habis Medieval Exegesis karya monumental de Lubac. Namun bagi Barthes dan filsuf postmodernisme Perancis lainnya, teks mempunyai banyak makna (polysemy) karena pembacalah yang menciptakan makna bagi teks sedangkan bagi penafsir pra-modern dan de Lubac secara khusus, teks mempunyai banyak makna karena Allah menginspirasikan makna spiritual kepada pembaca, selain makna literal Kitab Suci.

Metode-metode pra-modern, di tengah berbagai kekurangannya, terutama adalah pandangan anti Yahudi dan pandangan yang merendahkan wanita, yang tentu saja berdampak dalam cara menafsirkan teks Kitab Suci, bukan berarti sepenuhnya salah dan harus ditinggalkan karena ketinggalan zaman dan sudah usang. De Lubac tidak pernah memaksudkan pembacanya untuk mengadopsi sepenuhnya metode hermeneutika pra-modern, tetapi ia memaksudkan supaya pembacanya dapat dengan kritis mengambil prinsip-prinsipnya seperti: makna Kitab Suci tidak hanya terbatas 
pada makna literal, kesatuan antara Perjanjian Lama dan Perjanjian Baru, kesatuan antara studi biblika dan teologi sistematika, dan teologi merupakan analisis teks Kitab Suci dan bukan refleksi terhadap konsep-konsep yang asing bagi Alkitab. ${ }^{54}$

Demikian juga, de Lubac tidak menolak metode analisis sejarah. Bahkan ia menyarankan untuk memakai metode apa pun untuk dapat memahami makna literal Alkitab dengan lebih benar dan bertanggung jawab. Namun, sebagaimana ditunjukkan oleh de Lubac, makna literal saja tidak cukup. Penelitian Alkitab modern tidak dapat menangkap keseluruhan makna dari teks Alkitab. Karena itu, teologi eksegesis Henri de Lubac tentang berbagai level makna dalam pembacaan Alkitab pra-modern bisa dipertimbangkan menjadi salah satu cara yang bisa dipakai untuk mengintegrasikan kembali studi biblika dan teologi sistematika, eksegesis dan spiritualitas, sebagaimana yang terus diupayakan oleh para sarjana penganut Theological Interpretation of Scripture (TIS). Dengan demikian apa yang telah diceraikan oleh Gabler dan Jowett dapat disatukan kembali.

54. Daniel Treir dan Ucher Anizor, "Theological Interpretation of Scripture and Evangelical Systematic Theology: Iron Shaping Iron?" The Southern Baptist Journal of Theology 14/2 (2010). Treir dan Anizor mengkritik beberapa metode hermeneutika pra-modern yang de Lubac apresiasi, namun juga mendorong kaum Injili untuk menerapkan prinsipprinsip yang baik dari hermeneutika pra-modern yang de Lubac sangat yakini. 


\section{Daftar Pustaka}

Allison, Gregg R. "Theological Interpretation of Scripture: An Introduction and Preliminary Evaluation." Southern Baptist Journal of Theology 14/2 (2010): 28-36.

Ayres, Lewis. "The Soul and the Reading of Scripture: a Note on Henri de Lubac." Scottish Journal of Theology 61/2 (Mei 2008): 17390.

Balthasar, Hans Urs von. The Theology of Henri de Lubac. Diterjemahkan oleh J. Fessio, S.J. San Francisco: Ignatius, 1991.

Bartholomew, Craig G. "Biblical Theology." Dalam Dictionary for Theological Interpretation of the Bible (DTIB). Diedit oleh Kevin J. Vanhoozer et al. Grand Rapids: Baker Academic, 2005: 84-90.

Billings, J. Todd. The Word of God for the People of God: An Entryway to the Theological Interpretation of Scripture. Grand Rapids: Eerdmans, 2010.

Bray, Gerald, ed., "1-2 Corinthians." Dalam Ancient Christian Commentary on Scripture NT 7. Illinois: InterVarsity, 1999.

Bray, Gerald. "The Church Fathers and Biblical Theology." Dalam Out of Egypt: Biblical Theology and Biblical Interpretation, diedit oleh Craig Bartholomew, et. al. Grand Rapids: Zondervan, 2004: 23-40.

Carson, Donald A. "Theological Interpretation of Scripture: Yes, But . .." Dalam Theological Commentary: Evangelical Perspective, diedit oleh Michael Allen. London: T \& T Clark, 2011: 187-207. de Lubac, Henri. "Spiritual Understanding." Dalam The Theological Interpretation of Scripture: Classic and Contemporary Readings. Diedit oleh Stephen Fowl. Oxford: Blackwell, 1997: 3-25.

Medieval Exegesis: The Four Senses of Scripture, vol. 1. Diterjemahkan oleh Mark Sebanc. Grand Rapids: Eerdmans, 1998.

Hall, Christopher. Reading Scripture with the Church Father. Downers Grove: InterVarsity, 1998. 
Holsinger, Bruce. The Premodern Condition: Medievalism and the Making of Theory. Chicago: University of Chicago Press, 2005. Packer, James I. Keep in Step with the Spirit: Finding Fullness in Our Walk with God. Grand Rapids: InterVarsity, 2005.

Scobie, Charles H. H. The Ways of Our God: An Approach to Biblical Theology. Grand Rapids: Eerdmans, 2003.

Steinmetz, David C. "The Superiority of Pre-Critical Exegesis." Dalam The Theological Interpretation of Scripture: Classic and Contemporary Readings. Diedit oleh Stephen Fowl. Oxford: Blackwell, 1997: 26-38.

Storer, Kevin. "Theological Interpretation and the Spiritual Sense of Scripture: Henri de Lubac's Retrieval of a Christological Hermeneutic of Presence." Journal of Theological Interpretation 7/1 (2013): 79-96.

Treier, Daniel. Introducing Theological Interpretation of Scripture: Recovering a Christian Practice. Grand Rapids: Baker Academic, 2008.

Treir, Daniel dan Ucher Anizor. "Theological Interpretation of Scripture and Evangelical Systematic Theology: Iron Shaping Iron?" The Southern Baptist Journal of Theology 14/2 (2010): 4-17.

Trimm, Charles. "Evangelicals, Theology, and Biblical Interpretation: Reflections on the Theological Interpretation of Scripture." Bulletin for Biblical Research 20/3 (2010): 311-30.

Wood, Susan K. Spiritual Exegesis and the Church in the Theology of Henri de Lubac. Grand Rapids: Eerdmans, 1998.

Wright, William M. "The Literal Sense of Scripture According to Henri de Lubac: Insights from Patristic Exegesis of the Transfiguration. Modern Theology 28/2 (April 2012): 253-77. 